\title{
Dinoflagellate bloom in tropical fish ponds of coastal waters of the South China Sea
}

\begin{abstract}
Red tide of dinoflagellate was observed in brackish water fish ponds of Terengganu along the coast of the South China Sea during the study period between January 1992 to December 1992. The nearby coastal moat water facing the South China Sea is the source of water for fish pond culture activities of sea bass during the study period. An examination of water quality in fish ponds during the study period indicated that both the organic nutrients were high during the pre-wet monsoon period. The source of the nutrients in coastal water was believed to be derived from the agro-based industrial effluents, fertilizers from paddy fields and untreated animal wastes. This coincided with the peak production of dinoflagellate in the water column in October 1992. The cell count ranges from 8.3 to $60.4 \times 10.4 \times 104 / 1$ during the bloom peak period and the bloom species were compared entirely of non-toxic dinoflagellates with Protoperidinium quinquecorne occurring $>90 \%$ of the total cell count. However, both cultured and indigenous fish species were seen to suffer from oxygen asphyxiation (suffocation due to lack of oxygen). The bloom lasted for a short period (4ï 5 days) with a massive cell collapse from subsurface to bottom water on the sixth day. The productivity values ranged from $5 \mathrm{ï} 25 \mathrm{C} \mathrm{g/} 1$ / h with a subsurface maximum value in October 1992. Two species of Ciliophora, Tintinnopsis and Favella, were observed to graze on these dinoflagellates at the end of the bloom period.
\end{abstract}

Keyword: Dinoflagellate; South China Sea; Water quality 